\title{
Product Variety, Supply Chain Complexity and the Needs for Information Technology: A Framework Based on Literature Review
}

\author{
Estu Rizky Huddiniah \\ Faculty of Information and Communication Technology, Information Systems Department, \\ Institut Teknologi Sepuluh Nopember, Surabaya, Indonesia \\ Email: esturizky@gmail.com \\ Mahendrawathi ER \\ Faculty of Information and Communication Technology, Information Systems Department, \\ Institut Teknologi Sepuluh Nopember, Surabaya, Indonesia \\ Email: mahendra_w@is.its.ac.id (Corresponding Author)
}

\begin{abstract}
Recently, many companies are competing against each other to be the first to offer new product in the market, even when offering new products brings additional challenges for their operations. At the same time, information technology is chosen as the most effective solution to help company facing supply chain problems that arise due to increasing flow of materials and information in the supply chain. However, many companies still do not fully considered the importance of aligning the needs of information technology with the supply chain and business conditions. This paper conduct a structured literature review on the influence of product variety, supply chain complexity, and the needs level of information technology. Based on the literature review a conceptual framework is developed that highlight three propositions: the potential relations between product variety and supply chain complexity, supply chain complexity and information technology, and the importance of aligning the implementation of information technology with the company's business condition. Finally, the main propositions from this study is that there are potential connections among product variety, supply chain complexity, business condition and information technology.
\end{abstract}

Keywords: product variety, supply chain complexity, business condition, information technology.

\section{INTRODUCTION}

The current business environment including trends towards innovation, globalization of markets, increasingly demanding customers, and technological advancement have forced companies to be more innovative and offer a variety of products (Ross and Mocker, 2017; Shou et al., 2017)). Market trend is the most influential factor in the phenomena of product variation and product customization. Companies must quickly respond to the changing trend of public interest. Increasing product variety is claimed as a strategy to achieve more profitable market share and to win the business competition among global competitors. Companies ambition to be the pioneer in the market made them "Addicted to Innovation" (Ross and Mocker, 2017). These companies offer a large variety of products and blind to the challenges that it may cause (Cole, 2010; Ross and Mocker, 2017; Shou et al., 2017). Higher product variety create challenges in manufacturing these products as the number of components and interaction among these components causes a high degree of product complexity (Novak and Eppinger, 2001). The product variety and complexity in manufacturing has created numerous new challenges for supply chain management (Perona and Miragliotta, 2004; Khan and Creazza, 2009; Randall et al., 2011; ElMaraghy et al., 2013; Inman and Blumenfeld, 2014; Bode and Wagner, 2015).

Supply chain is a network of companies that works together to deliver product/ service from upstream to downstream supply chain. One of the key aspects in supply chain is managing information and material exchanges between functions and activities (Cooper and Ellram, 1993; Cooper, Lambert and JD, 1997; Motiwalla and Thompson, 2012). The complexity of supply chain network is defined as aspects or components that are integrated and connected with each other on supply chain network. A number of studies has linked the supply chain complexity with product variety and product complexity. In the context of supply chain, integration has a significant effect to the supply chain sustainability. Integration enable companies and supply chain network component to work together as a single unified and cohesive entity (Welker, van der Vaart and Pieter van Donk, 2008). Supply chain integration refers to the information sharing between component or partner in the supply chain networks. The information sharing includes all data types that affect collaboration and coordination among supply chain partners, i.e. demand information, inventory status, production schedules, purchase orders, shipment schedules, etc. (Welker, van der Vaart and Pieter van Donk, 2008; Motiwalla and Thompson, 2012).

Information technology (IT) acts as a provider of infrastructure and services that enable more effective and efficient information exchange among supply chain partners (Auramo, Kauremaa and Tanskanen, 2005; Welker, van der Vaart and Pieter van Donk, 2008; Zhang, Pieter van Donk and van der Vaart, 2011; Shou et al., 2017). In general, the role of IT in supply chain network includes four objectives: ensuring information availability and visibility, enabling 
single point of contact to centralized data, aiding decision making based on data and information obtained from supply chain network, and supporting collaboration and coordination among supply chain partners. While IT promised various benefits, it does not guarantee positive results if it is not aligned with the company's business condition (Auramo, Kauremaa and Tanskanen, 2005; Welker, van der Vaart and Pieter van Donk, 2008). Many companies implement IT without taking into account the company's current business condition. Meanwhile, it is important for companies to align the current business condition with the needs level of information technology, so that companies will obtain the maximum value from the implementation of information technology. The issues of increasing product variety and consequently rapid information exchanges in the supply chain network in one hand, and the use of information technology in another, are inter-related. The literature to date have addressed these issues separately. A more comprehensive study addressing these aspects simultaneously promises fruitful area of research.

This paper conducts a systematic literature review to gain deep understanding on the potential relationships among these aspects. A systematic literature review is expected to provide a deeper knowledge and could generate an idea for the future research on these areas. First, a review on some of the fundamental aspects of the study including product variety, supply chain and supply chain complexity, and IT in supply chain is provided in section 2 . Section 3 describes the methodology of this paper including the process of literature selection and assessment. The issues related to the impact of product variety, supply chain complexity, and the use of information technology in the supply network are discussed in section 4. Section 5 describes the research gaps obtained from the literature review that provide areas for the further research. Finally, the conclusions are described in the final section.

\section{BACKGROUND}

\subsection{Product Variety}

Companies have to respond to the public interest in design, function, colour, size, packaging, and product accessories rapidly in order to fulfil the customers need (Cooper and Ellram, 1993; Lambert, Cooper and Pagh, 1998; Wan, Evers and Dresner, 2012; ElMaraghy et al., 2013; Shou et al., 2017). Product variety have been considered by many companies as a beneficial strategy offering various benefits namely increasing the volume of revenue and sales (ElMaraghy et al., 2009). However, managing product variety over time is not an easy task. Too much variety can be contra productive from business perspective (Pujawan, Er and Somboonwiwat, 2014). Higher product variety will have an impact to the complexity of companies, especially in managing the production, procurement, and distribution processes (ElMaraghy et al., 2013). Increasing product variety will affect the increasing number of components and the interactions between the components to make finished product (Shou et al., 2017).

Product variety closely related to product complexity. In general, product complexity is defined as the number of components or raw material needed to make finished product and the relationship between each component in production process (Bode and Wagner, 2015). Companies that have high product complexity have to be prepared to face the complex problem in managing inventory and capacity (Shou et al., 2017). Therefore, it is important for companies to offer the right level of product variety in order to meet demand of customers, but still maintain the alignment of their supply chain network. In order to maximize the long-term profits, companies must balance between the increase in benefits with the costs of offering product variety (Motiwalla and Thompson, 2012).

\subsection{Supply Chain}

Supply chain is a network of business entities that deliver product or services from upstream to downstream, and must manage the intensity of information exchange between functions and activities in it (Cooper and Ellram, 1993; Cooper, Lambert and JD, 1997; Lambert, Cooper and Pagh, 1998; Motiwalla and Thompson, 2012). Based on the Council of Supply Chain Management Professional (CSCMP), supply chain is identical to a complex system with a series of activities including planning and managing the entire process in supply chain network. Supply chain also consists of simultaneous interaction between companies and channel or partners in uncertain conditions (Sivadasan et al., 2002, 2006, 2010, 2013; Motiwalla and Thompson, 2012). The main key to effectively manage a supply chain network is to manage the process of coordination and integration between supply chain network component (channel/partner) and supply chain network flow (Motiwalla and Thompson, 2012).

There are three flows in a supply chain including: product, information, and financial flows (Motiwalla and Thompson, 2012). Product flow includes the exchange of goods (finishing product) between channels/ partners, such as the exchange of raw material used in the production process from suppliers to companies through the procurement process, or consumers making purchases of product to the companies (sales orders) (Wagner and Weidner, 2016b). Information flow includes the process of information sharing between channels/ partners, such as the information about the amount of material purchased by companies to suppliers (purchase order), or the number of product order by consumers to the companies (sales orders), delivery time, and shipment schedule (Wagner and Weidner, 2016a). Financial flow includes the exchange of value or financial information between channels/ partners taking the form of money or revenue, such as payment schedules, invoices, or delivery costs (Wagner, Weidner and Boldau, 2016). By creating the effective coordination and integration in all these flows, companies are able to rapidly improve the efficiency in the supply chain and quickly respond to the demand from each partner.

\subsection{Supply Chain Complexity}

Supply chains are determined as networks of organizations where each node is connected to each other from upstream to downstream with different processes and activities to produce a value in the products or services (Mentzer et al., 2001; Motiwalla and Thompson, 2012). Complexity is associated with a system which is difficult to understand, explain, predict and manage. The complexity of supply chain networks is defined as the complexity of flow 
in supply chain networks involving various components and interconnected aspects (Bode and Wagner, 2015). These components and aspects include number of interactions, degree of interaction, degree of structural order, level of variety and degree of uncertainty (Choi and Hong, 2002; Sivadasan et al., 2002; Cheng, Chen and Chen, 2014; Bode and Wagner, 2015).

There are various opinions in determining and measuring the complexity of a supply chain network. Many studies view supply chain complexity as a multi-dimensional phenomena based on various influential factors. These factors can be distinguished according to the scope and specifications of parts or segments of the research (Bode and Wagner, 2015). Mentzer et al. (2001) defines the degree of supply chain complexity into three categories: direct supply chain, extended supply chain, dan ultimate supply chain. Direct supply chain consists of companies, suppliers and consumers involved in the flow of products / services, finance, and information from upstream to downstream. Extended supply chain is a supply chain including suppliers from major suppliers and also consumers from the main consumers that involved in the flow of products / services, finance, and information from upstream to downstream. Ultimate supply chain is a supply chain including all organizations involved in the supply chain network flow from upstream to downstream. Ultimate supply chains are the most complex supply chain.

Choi and Hong (2002) define supply chain complexity as differences or variations existing within an organization, influenced by the number of sub-systems or the level of interaction in the organization. Choi and Hong (2002) propose three types of measures of supply chain complexity: horizontal complexity, vertical complexity, dan spatial complexity. Horizontal complexity refers to the number of different entities at the same level which can be measured according to the number of suppliers in each tier. Vertical complexity refers to the number of levels existing in the system measured by the number of tiers involved in the supply chain network. Spatial complexity refers to the number of operating locations or levels of dispersion between members in the system, which can be measured based on the average distance between two companies that are mutually bound in the process of buying and supplying.

\subsection{Information Technology in Supply Chain}

Implementation of Information Technology (IT) in the industrial world is one of strategies to help companies to improve the productivity of their business processes. IT provides a mean for companies to access real-time information needed to maintain the sustainability of the company's business processes, while supporting companies for more effective and efficient decision making process (Auramo, Kauremaa and Tanskanen, 2005). In the context of supply chain, the impact of technology can be categorized into two aspects: supply chain integration and supply chain performance (Zhang, Pieter van Donk and van der Vaart, 2011; Motiwalla and Thompson, 2012). Supply chain integration is a key to achieve success in supply chain networks. An important factor in supply chain integration is to improve coordination and collaboration between partners in the supply chain networks.
In order to integrate the whole interaction process between partners in a supply chain network, companies must pay attention to the aspects of sharing and access (Sivadasan et al., 2002; Welker, van der Vaart and Pieter van Donk, 2008; Motiwalla and Thompson, 2012; Shou et al., 2017). Sharing dan access in this case means that elements of supply chain networks have to be able to fully cooperate in exchanging and allowing access to important information to achieve more responsive, effective and efficient supply chain networks (Motiwalla and Thompson, 2012). Information technology is needed to facilitate rapid flow of information between supply chain networks (Motiwalla and Thompson, 2012). The application of IT enables more effective and efficient information exchange and improve the quality of information received by each partner so that supply chain integration can be realized (Zhang, Pieter van Donk and van der Vaart, 2011; Zhou et al., 2014). With the achievement of sharing and access aspects in supply chain networks, the collaboration and coordination between company partner channels can be realized in order to create successful supply chain integration.

Companies can get a lot of benefits from supply chain integration, one of which is improvement in supply chain and the company's business processes performance (Qrunfleh and Tarafdar, 2014). Increasing a company's supply chain performance means the company's ability to manage the company's business processes more effectively and efficiently. The increase in supply chain performance is identical to the increase of revenue and profit obtained by the company. Several studies indicated that IT has direct effects on increasing supply chain performance (Zhang, Pieter van Donk and van der Vaart, 2011; Qrunfleh and Tarafdar, 2014). The use of IT makes it easier for companies to exchange information directly, which in turn results in the improvement of supply chain performance (Zhang, Pieter van Donk and van der Vaart, 2011).

As stated above, there is intercorrelation among product variety, supply chain complexity and information technology. Product variety and supply chain complexity may influence the needs level of information technology for companies, while IT may affect the integrity and performance of business process and management of supply chain in the companies. Therefore, in this paper a deeper review and analysis of the relationship among product variety, supply chain complexity, and IT will be conducted based on previous studies, in order to develop a conceptual framework which can be used as references for further research in the future.

\section{RESEARCH METHODOLOGY}

The main purpose of this paper is to review various literature related to the impact of product variety, supply chain complexity, and the needs level of information technology. This paper follows the step of systematic literature review as proposed by Kitchenham et al. (2009), which include:

1. Define the research question.

2. Design the plan.

3. Search for literature.

4. Apply exclusion and inclusion criteria.

5. Apply quality assessment.

6. Synthesis. 
In the first step, the research question is defined as follow: what is the current state-of-the-art of research in product variety, supply chain complexity and the needs for IT implementation?

The next step is to design the literature review process including the scope of the literature review. This paper collected research from various literature studies especially in the areas of Business, Management and Accounting, Computer Science, Decision Sciences, Economics, Econometrics and Finance, Engineering, Materials Science, and Mathematics. Then, combination of several keywords including product variety, supply chain complexity, supply chain integration, information sharing and information technology are used in the search process. Two databases are used including Emerald Insight and Science Direct.

The combination of keywords and results obtained from the search are summarized in Table 1. It can be seen that different results are obtained from different combination of keywords. Keywords supply chain combined with Information Technology or information sharing gave more results in comparison to product variety or product complexity. To filter the literature, several inclusion criteria are determined as follow:
1. Journal article

2. English language

3. Time of publication between $2010-2017$

Conference papers, book chapter or any other publication are excluded.

After filtering based on the inclusion and exclusion criteria, the literature is assessed based on several criteria. The first criterion is the relevance of the literature to answer the research question. Thus, the abstract of the paper is perused to assess its relevance to the topic of product variety, product complexity, supply chain complexity and information technology. The second criterion is the credibility of the publication. The selected journals are based on the standard and quality indicators including impact factors, impact by scientists or scholar, and most cited journal. The indicator is obtained through SCImago Journal Rank (SJR), which provides indexed information of journals on Scopus. Based on the process described previously, 20 research papers are chosen for further review and analysis. These literatures are perused in more detail to answer the research question.

Table 1 Search result based on keyword research

\begin{tabular}{|c|c|c|c|c|c|c|}
\hline \multicolumn{3}{|c|}{ Keywords } & \multirow{2}{*}{\multicolumn{2}{|c|}{ Emerald Insight }} & \multirow{2}{*}{\multicolumn{2}{|c|}{ Science Direct }} \\
\hline \multirow{2}{*}{ First Keyword } & \multirow{2}{*}{ Second Keyword } & \multirow{2}{*}{ Third Keyword } & & & & \\
\hline & & & All Years & 2010-Present & All Years & 2010-Present \\
\hline \multirow{11}{*}{ 'Product Variety' } & 'Information Technology' & - & 56 & 17 & 102 & 35 \\
\hline & 'Information Sharing' & - & 20 & 15 & 34 & 14 \\
\hline & \multirow{3}{*}{ 'Supply Chain' } & - & 52 & 26 & 103 & 63 \\
\hline & & 'Information Technology' & 4 & 1 & - & - \\
\hline & & 'Information Sharing' & - & - & - & - \\
\hline & \multirow{3}{*}{ 'Supply Chain Complexity' } & - & 14 & 8 & 3 & 3 \\
\hline & & 'Information Technology' & 1 & - & - & - \\
\hline & & 'Information Sharing' & - & - & - & - \\
\hline & \multirow{3}{*}{ 'Supply Chain Integration' } & - & 15 & 12 & 15 & 10 \\
\hline & & 'Information Technology' & - & - & - & - \\
\hline & & 'Information Sharing' & - & - & - & - \\
\hline \multirow{11}{*}{ 'Product Complexity' } & 'Information Technology' & - & 140 & 62 & 94 & 46 \\
\hline & 'Information Sharing' & - & 43 & 24 & 38 & 38 \\
\hline & \multirow{3}{*}{ 'Supply Chain’ } & - & 132 & 72 & 124 & 75 \\
\hline & & 'Information Technology' & 13 & 8 & - & - \\
\hline & & 'Information Sharing' & 6 & 3 & - & - \\
\hline & \multirow{3}{*}{ 'Supply Chain Complexity' } & - & 132 & 72 & 124 & 75 \\
\hline & & 'Information Technology' & 13 & 8 & - & - \\
\hline & & 'Information Sharing' & 6 & 3 & - & - \\
\hline & \multirow{3}{*}{ 'Supply Chain Integration' } & - & 41 & 24 & 13 & 11 \\
\hline & & 'Information Technology' & 5 & 3 & - & - \\
\hline & & 'Information Sharing' & 1 & - & - & - \\
\hline \multirow{2}{*}{ 'Supply Chain' } & 'Information Technology' & - & 377 & 161 & 435 & 246 \\
\hline & 'Information Sharing' & - & 216 & 115 & 433 & 271 \\
\hline \multirow{2}{*}{$\begin{array}{l}\text { 'Supply Chain } \\
\text { Complexity' }\end{array}$} & 'Information Technology' & - & 42 & 24 & 116 & 63 \\
\hline & 'Information Sharing' & - & 20 & 11 & 73 & 43 \\
\hline \multirow{2}{*}{$\begin{array}{l}\text { 'Supply Chain } \\
\text { Integration' }\end{array}$} & 'Information Technology' & - & 148 & 65 & 35 & 22 \\
\hline & 'Information Sharing' & - & 67 & 37 & 19 & 15 \\
\hline
\end{tabular}




\section{RESULTS}

The literature can be classified into three main categories: literature that relates product variety and supply chain complexity, literature that address business conditions and supply chain complexity, and literature that relate business condition, supply chain complexity and information technology. Each of these categories will be addressed in the following section.

\subsection{Product Variety and Supply Chain Complexity}

The enhancement of global market competition, growing number of new products in the market, more flexible and adaptive manufacturing systems are the reasons for companies to generate more innovative product variety. Today, product variety is considered as a strategy to increase the chances for companies to win market competition and gain profit i.e. increase the income and sales volume. But, in order to maximize the long-term profits, companies are required to be able to harmonize between the benefits obtained by increasing variety product and the cost of production (Motiwalla and Thompson, 2012).

Table 2 summarizes the literature classified in the first category. In their study, Shou et al. (2017) adopted Fisher et al. (1999) definition of product variety i.e. the breadth of products that a company offers at a given time. Product complexity is defined as the number of parts or components needed to build the product. Bode and Wagner (2015) summarized product complexity as static complexity (number and variety of elements) and dynamic complexity (interactions between elements). Shou et al. (2017) argue that increasing product variety lead to difficulties in manufacturing due to large number of product components and interaction among components i.e. higher product complexity.

Authors relate product variety and complexity with supply chain complexity. Aitken et al. (2016) proposed several categories of factors that affect supply chain complexity: type (detail/ dynamics), origin (upstream, downstream, or internal business unit), and business strategy (strategic or dysfunctional). Gimenez et al. (2012) listed product variety along with order winners, volume, variety, lead time, percentage of MTO/ MTS, batch size as representation of the factors that determine the complexity of the ordering, manufacturing, and delivering process to supplier-buyer relationship.

Many other authors also highlight the challenge that arise in introducing high product variety. ElMaraghy et al. (2013) explained that the higher product variation will influence the complexity of supply and assembly processes. In the assembly processes, the high variation and complexity will lead to human error and affect systems performance. In addition, the increasing of product variety also has an impact in increasing budget, cost, and longer process time. These statements are supported by Inman and Blumenfeld (2014) who explain that the more unique and varied components in assembling of a product, the higher the risk to be faced. These problems will certainly influence the cost that must be borne by companies.

Inman and Blumenfeld (2014) claim that there is an affinity between product variety and product complexity to the complexity of supply chain disruption. In line with Inman dan Blumenfeld's claims, Bode and Wagner (2015) investigate factors that influence supply chain complexity and disruption. They model three main variables i.e. frequency of supply chain disruptions as the dependent variable, supply chain complexity dimension as the independent variable and firm size, firm age, competitive intensity, and industry as control variables. Moreover, Shou et al. (2017) claim that increasing product variety and product complexity will affect the complexity of a company's business process such as transaction, coordination and collaboration processes in the supply chain networks. Therefore, it is important for companies to plan the business systems carefully before deciding to add product variety. The aim of the planning is to ensure that product variety can provide values and benefits for the companies.

Table 2 Literature on product variety and supply chain complexity

\begin{tabular}{|c|c|c|}
\hline Reference & Focus & Methods \\
\hline Shou et al (2017) & $\begin{array}{l}\text { Explore the drivers of supply chain integration based on product } \\
\text { level with governance theory and knowledge-based view. }\end{array}$ & $\begin{array}{l}\text { Quantitative, survey-based strategy, } \\
\text { structural equation modeling. }\end{array}$ \\
\hline El Maraghy et al (2013) & $\begin{array}{l}\text { Explore the variations, methods and strategies to manage } \\
\text { product variety and product variety drivers complexity. }\end{array}$ & analysis-based method. \\
\hline Bode \& Wagner (2015) & $\begin{array}{l}\text { Examine the correlation of supply chain risk management and } \\
\text { supply chain complexity disruption in the upstream-supply side } \\
\text { (structural driver of supply chain complexity). }\end{array}$ & $\begin{array}{l}\text { Quantitative, } \quad \text { multidimensional } \\
\text { regression, case-based analysis, } \\
\text { multivariance analysis of variance. }\end{array}$ \\
\hline Aitken et al (2016) & $\begin{array}{l}\text { Explore the distinction of strategic and dysfunctional supply } \\
\text { chain complexity to develop supply chain complexity strategic } \\
\text { (absorb or reduce) in the individual business unit perspective. }\end{array}$ & $\begin{array}{l}\text { Qualitative, coefficient of variation (CoV), } \\
\text { case-based analysis. }\end{array}$ \\
\hline Gimenez et al (2012) & $\begin{array}{l}\text { Explore the integration of supply chain (effectiveness and } \\
\text { performance) in the supplier-buyer relationships based on } \\
\text { supply chain complexity characteristics. }\end{array}$ & $\begin{array}{l}\text { Qualitative, statistic-based method, case- } \\
\text { based analysis (MTO/ MTS). }\end{array}$ \\
\hline $\begin{array}{l}\text { Inman } \& \text { Blumenfeld } \\
(2014)\end{array}$ & $\begin{array}{l}\text { Develop a mathematical model to evaluate the impact of product } \\
\text { complexity for mitigation and prevention of supply chain } \\
\text { disruption. }\end{array}$ & $\begin{array}{l}\text { Quantitative, missing parts on supply } \\
\text { chain risk assessment method, case- } \\
\text { based analysis (ATO/ ETO). }\end{array}$ \\
\hline
\end{tabular}




\subsection{Business Conditions and Supply Chain Complexity}

Supply chain is commonly defined as a complex network of business entities involving upstream to downstream flow of products or services as well as the intensity of material and information exchanges between functions. Table $\mathbf{3}$ shows the literature on business conditions and supply chain complexity. In the context of supply chain network, business conditions are defined as conditions that leverage the complexity of supply chain network such as decoupling point strategy, volume-variety materials and products, process type, lead time, etc (Vaart and Donk, 2006). de Leeuw et al. (2013) represented the supply chain complexity as an interaction between different aspects of supply chain network. These aspects consist of the number of elements, degree of interaction, degree of structural order, level of variety and diversity, and the degree of uncertainty (Sivadasan et al., 2002; de Leeuw, Grotenhuis and van Goor, 2013; Cheng, Chen and Chen, 2014). The complexity itself may led to inefficiencies and inflexibility, long lead-times, reduces financial and delivery performance (de Leeuw, Grotenhuis and van Goor, 2013).

Many authors have utilised qualitative or quantitative approach to investigate the issue of supply chain complexity. Vaart and Donk (2006) propose a qualitative method to determine the suitability of business condition with the supply chain integration of make-to-order and make-to-stock companies. They associated the company's business condition with the complexity of supply chain network based on the degree of individuality of buyer-focused operation as supply chain strategy to maintain the relationship of key buyers. Welker et al. (2008) claim that business condition characteristics refer to the supply chain complexity and determine the level of information and material exchange within company. Business condition is divided into two categories, simple business condition and complex business condition. They used a qualitative method to determine supply chain complexity in different business conditions based on company's entities such as order winner, products and process characteristics, variety of demand, delivery time, and customer order decoupling point.
Supply chain complexity could be clustered by the interrelated characteristics within systems and divided into structural complexity and operational complexity (Sivadasan et al., 2002, 2013; de Leeuw, Grotenhuis and van Goor, 2013; Cheng, Chen and Chen, 2014). Operational complexity is associated with interaction between components in the system, which continuously change and refers to the degree of predictability and uncertainty within the systems. Structural complexity is associated with a variety of components in a static and fixed system, which is related to number and variety of elements defining the systems.

Sivadasan et al (2013) proposed quantitative methods to measure the level of supply chain complexity in different characteristics of business conditions using operational complexity approach. The characteristic of business condition is divided into commodity production companies (make-to-order) and customizing production companies (make-to-stock). They claim that the level of supply chain complexity depends on the uncertainty characteristics associated with the material and information flows (Sivadasan et al., 2002, 2006, 2013). Uncertainty characteristics of information and material flow defined and measured as diversion of scheduled plan in the systems, and it will increase in line with uncertainty component within systems.

Different with Sivadasan et al (2013) who apply operational complexity approach to measure supply chain complexity, Cheng et al. (2014) conducted a quantitative method to measure supply chain complexity using structural complexity approach. Cheng et al. (2014) combined several entropy models to determine the dimensions affecting the component of structural complexity systems that categorized by degree of order and diversity. Degree of order is associated with degree of connection between individual members in supply chain and other member of the supply chain. Diversity is illustrated by the number of variations in supply chain networks and more variations in supply chain networks will make supply chain structure more complex and diverse.

Table 3 Literature on business conditions and supply chain complexity

\begin{tabular}{|c|c|c|}
\hline Reference & Focus & Methods \\
\hline $\begin{array}{l}\text { Welker et al } \\
\text { (2008) }\end{array}$ & $\begin{array}{l}\text { Explore information sharing system in several business } \\
\text { condition and the role of information technology in the supply } \\
\text { chain network. }\end{array}$ & $\begin{array}{l}\text { Qualitative, case-based analysis (small medium } \\
\text { enterprise, MTO/MTS). }\end{array}$ \\
\hline $\begin{array}{l}\text { Sivadasan et al } \\
\text { (2002) }\end{array}$ & $\begin{array}{l}\text { Propose an operational complexity framework to measure the } \\
\text { level of supply chain complexity between supplier-customer } \\
\text { systems based on the information flow and product transfer. }\end{array}$ & $\begin{array}{l}\text { Quantitative, information-theoretic entropy, } \\
\text { case-based analysis. }\end{array}$ \\
\hline $\begin{array}{l}\text { Sivadasan et al } \\
\text { (2006) }\end{array}$ & $\begin{array}{l}\text { Examine the operational complexity of supply chain (supplier- } \\
\text { customer systems) based on information theoretic model. }\end{array}$ & $\begin{array}{l}\text { Quantitative, mathematic modelling, systematic } \\
\text { hierarchical approach. }\end{array}$ \\
\hline $\begin{array}{l}\text { Sivadasan et al } \\
\text { (2013) }\end{array}$ & $\begin{array}{l}\text { Investigate the correlation between supply chain partners } \\
\text { (supplier-customer) with schedule instability based on the } \\
\text { information exchange between partner (complexity-adding } \\
\text { information flow). }\end{array}$ & $\begin{array}{l}\text { Quantitative, information theoretic method, case- } \\
\text { based analysis (commodity production } \\
\text { environment and commodity customized } \\
\text { production). }\end{array}$ \\
\hline $\begin{array}{l}\text { Van Der Vaart \& } \\
\text { Van Donk (2006) }\end{array}$ & $\begin{array}{l}\text { Explore the influence of business conditions and characteristics } \\
\text { to the supply chain strategy and operation for better relationship } \\
\text { with key buyers. }\end{array}$ & Qualitative, case-based analysis (MTO/MTS). \\
\hline $\begin{array}{l}\text { de Leeuw et al } \\
\text { (2013) }\end{array}$ & $\begin{array}{l}\text { Propose methodology of supply chain complexity assessment in } \\
\text { the distributive trade/ wholesaler. }\end{array}$ & $\begin{array}{l}\text { Quantitative, entropy-based studies (static and } \\
\text { dynamic complexity), qualitative, case-based } \\
\text { analysis. }\end{array}$ \\
\hline
\end{tabular}




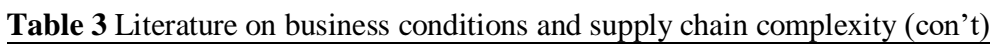

\begin{tabular}{lll}
\multicolumn{1}{c}{ Reference } & \multicolumn{1}{c}{ Focus } & \multicolumn{1}{c}{ Methods } \\
\hline Cheng et al & Propose mathematical entropy model based on information theoretic modelling to & Quantitative, information- \\
(2014) & measure structural complexity of supply chain (supplier-customer systems). & theoretic entropy-based model. \\
\hline
\end{tabular}

\subsection{Information Technology Implementation and Supply Chain Network}

Integration has a very important and significant role in the context of supply chain. Integration allowed companies and each component in the supply chain network to work together as a single unified and cohesive entities (Auramo, Kauremaa and Tanskanen, 2005; Ye and Wang, 2013; Zhou et al., 2014; Kaliani Sundram, Chandran and Awais Bhatti, 2016). Table 4 summarize literature on information technology and supply chain network. To acquire the successful supply chain integration, companies must collaborate and coordinate among channel partners in the supply chain. This way, the companies can improve and stabilize the performance of company's supply chain network. One of the important aspects of integration in the supply chain networks is sharing and accessing information (Zhang, Pieter van Donk and van der Vaart, 2011; Vanpoucke, Vereecke and Muylle, 2017). The sharing and accessing aspects in this case mean that the supply chain network must be able to fully cooperate to the valuable information exchange and allow the supply chain network channel to access the information (Fuchs and Otto, 2015). The information exchange includes all types of data that affect collaboration and coordination process between supply chain network partners, such as information related to demand, inventory status, production schedules, purchase orders, shipment schedules, etc. Information technology acts as the provider, infrastructure and services enabling overall information to be interchanged more effectively and efficiently among supply chain network channels (Auramo, Kauremaa and Tanskanen, 2005; Zhang, Pieter van Donk and van der Vaart, 2011; Ye and Wang, 2013; Fuchs and Otto, 2015).

In general, the role of information technology in the supply chain network includes four objectives. The first objective consists of ensuring the availability, visibility, and quality of information (Zhou et al., 2014; Kaliani Sundram, Chandran and Awais Bhatti, 2016); second objective is allowing access from a single point of contact (centralized data) (Auramo, Kauremaa and Tanskanen, 2005); third objective is assisting in decision-making based on the data and information obtained from the supply chain network (Fuchs and Otto, 2015; Vanpoucke, Vereecke and Muylle, 2017) and the fourth objective is assisting the companies in the process of collaborating and coordinating with supply chain network channels (Kaliani Sundram, Chandran and Awais Bhatti, 2016; Vanpoucke, Vereecke and Muylle, 2017).

Table 4 Literature on Information Technology and Supply Chain Network

\begin{tabular}{|c|c|c|}
\hline Reference & Focus & Methods \\
\hline Auramo et al (2005) & $\begin{array}{l}\text { Explore the benefit of IT, the use of IT and IT solution in } \\
\text { supply chain management. }\end{array}$ & $\begin{array}{l}\text { Qualitative, case-based analysis, survey- } \\
\text { based methodology. }\end{array}$ \\
\hline Zhang et al (2011) & $\begin{array}{l}\text { Evaluate the correlation between IT, supply chain } \\
\text { management, supply chain integration and performance. }\end{array}$ & $\begin{array}{l}\text { Qualitative, survey-based methodology, } \\
\text { resource-based view, process-oriented } \\
\text { view. }\end{array}$ \\
\hline Zhou et al (2014) & $\begin{array}{l}\text { Examine the impact of IT and supply chain performance } \\
\text { based on the information quality to conduct effective } \\
\text { supply chain practice strategy (sourcing practice and } \\
\text { delivery practice). }\end{array}$ & $\begin{array}{l}\text { Quantitative, survey-based strategy, } \\
\text { clustering analysis, case-based analysis. }\end{array}$ \\
\hline Sundram et al (2016) & $\begin{array}{l}\text { Propose a framework to examine the complex } \\
\text { intercorrelation between supply chain management } \\
\text { practice, supply chain integration and performance based } \\
\text { on information sharing and quality. }\end{array}$ & $\begin{array}{l}\text { Quantitative, survey-based strategy, } \\
\text { structural equation modeling, case-based } \\
\text { analysis. }\end{array}$ \\
\hline F. Ye \& Z. Wang (2013) & $\begin{array}{l}\text { Explore the benefit of IT alignment on supply chain } \\
\text { operational performance based on information sharing } \\
\text { between supply chain partner. }\end{array}$ & $\begin{array}{l}\text { Quantitative, survey-based strategy, case- } \\
\text { based analysis (Chinese manufactures), } \\
\text { confirmatory factor analysis (CFA) average } \\
\text { percentage of variation (AVE). }\end{array}$ \\
\hline Vanpoucke et al (2017) & $\begin{array}{l}\text { Investigate interconnection of IT to the supply chain } \\
\text { integration and performance (upstream and downstream) } \\
\text { based on the volume and complexity of information } \\
\text { exchange. }\end{array}$ & $\begin{array}{l}\text { Quantitative, survey-bases strategy, case- } \\
\text { based analysis, correlation matrix. }\end{array}$ \\
\hline Fuchs \& Otto (2015) & $\begin{array}{l}\text { Explore the value of IT in supply chain planning and } \\
\text { propose optimization of IT functionality in supply chain. }\end{array}$ & $\begin{array}{l}\text { Qualitative, APS framework, supply chain } \\
\text { operations reference framework. }\end{array}$ \\
\hline
\end{tabular}




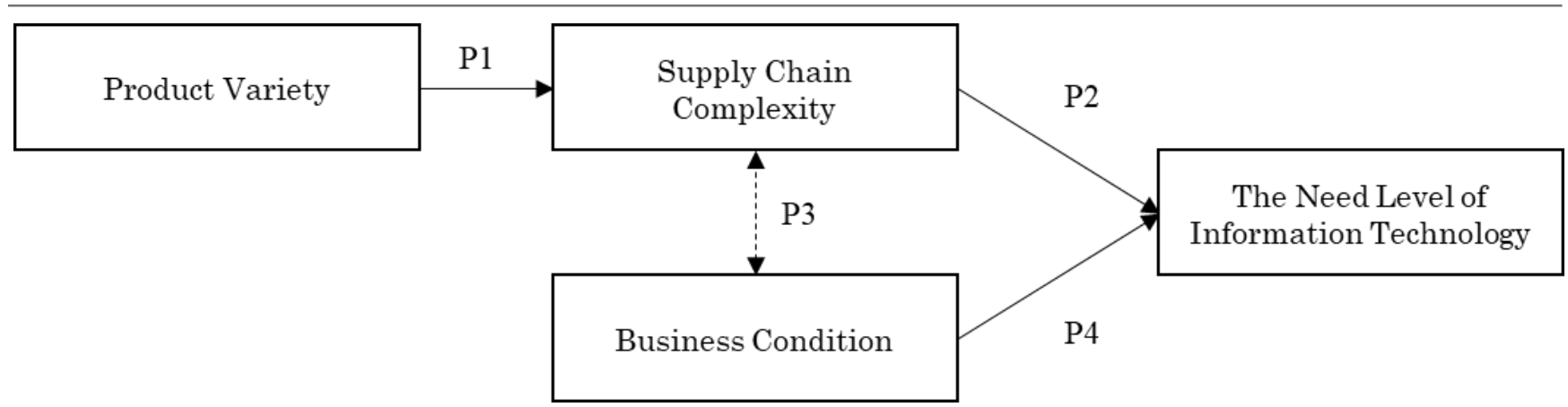

Figure 1 Conceptual Framework of the Correlation of Product Variety, Supply Chain Complexity, and the Need Level of Information Technology

\section{DISCUSSION AND FUTURE RESEARCH DIRECTION}

Based on the literature review, a conceptual framework is developed as shown in Figure 1. The framework describes the four areas of research: product variety, supply chain complexity, and the needs level of information technology. Based on the conceptual framework, several propositions can be obtained. Each proposition that provides direction for future research is discussed in this section

\section{P1. Product Variety to Some Extent Relates to Supply Chain Complexity}

As the variety of product increases, the complexity of the components needed to construct a finished product most likely will increase, which can be interpreted as product complexity. Product complexity is the complexity of all components required to produce the finished product. It is defined as the number of components or raw materials and the interrelationships among the components to produce the finished product. The increasing variety of products will have an impact on the increasingly complex network of business entities involved in the process of exchange of products or services, materials and information flow between supply chains. Companies which have high product variety, must be prepared to compromise with complicated issue in their business process, so it is essential for companies to harmonize their supply and demand.

This proposition leads to several interesting questions that need to be investigated further. To what extent does product variety influence the supply chain complexity? What kind of product variety is more pernicious to supply chain complexity? Finally, further study can attempt to investigate the level of product variety that satisfy the customer's demand while still manage the complexity of supply chain network.

\section{P2. There is a Correlation between Supply Chain Complexity and the Need for Information Technology}

Proposition 2 describes the correlation between supply chain complexity and the need for information technology. Information technology is chosen as a solution to offer convenience for the company in achieving the successful integration of its supply chain. The information technology relates closely with the issues of supply chain integration and information sharing. According to the previous research, there are a lot factors influencing the complexity of supply chain especially in terms of information exchange among supply chain channel. High-level supply chain complexity has a major effect on the low level of integration among supply chain partners to work together, coordinate and collaborate. The high complexity of the supply chain requires rapid flow of information exchanges between elements of the supply chain. It is therefore interesting to investigate several questions: does more complex supply chain lead to more complex information exchanges? Does more complex supply chain have higher need for information technology? Does more complex supply chain require more advanced information technology?

\section{P3. The Business Condition Need to Be Considered in the Implementation of Information Technology}

Proposition 3 highlights the potential relation between a company business condition and the implementation of information technology. There are certain aspects that must be considered by company in the implementation of IT to provide more benefit and value. These aspects relate to several company's current business condition i.e product variety, material variety, number of partner, type of company etc, to harmonize the company's business condition and the requirement of IT. The business condition determines the type of information exchange required by company and the degree of information exchanges to some extent influence the need for information technology.

Based on the previous literature review, there is only certain research that mention about business condition. Previous literature review only compares between two typical business conditions i.e. make-to-order (MTO) and make-to-stock (MTS). There are some other business conditions, which have significantly different characteristic compared to MTO and MTS, such as assembly-to-order (ATO), or engineer-to-order (ETO). Further investigation is required to compare the complexity of business conditions based on each customer decoupling point strategy and its impact on the information technology needs.

\section{P4. The connections of product variety, business conditions, supply chain complexity to the information technology}

Proposition 4 combines the previous propositions, highlighting the potential relationships between product variety, business conditions, and supply chain complexity to the implementation of information technology. Many authors have discussed the effect of product variety on supply chain complexity. Business condition to some extent also influence the supply chain complexity. Most of the researches conducted so far only discussed the benefits of 
information technology in general and ignoring the importance of aligning the needs level of information technology with supply chain complexity and business condition. So far, companies only apply information technology without considering the business conditions. This paper proposes that the complexity of the supply chain and business conditions can be important factors to measure the needs level of information technology. Implementation of information technology that is aligned with the company's business condition and supply chain complexity is expected to provide more value to the company.

Previous literature has typically examined two dimensions: the correlation between product variety and supply chain complexity, product variety and supply chain integration, supply chain complexity and information technology, and supply chain integration and information technology. There are only several research connecting the three dimensions of product variety, supply chain, and information technology. A deeper assessment of the relationship between the needs level of information technology and supply chain complexity is required. Further study can be done to simultaneously address the relationship between product variety, supply chain complexity and the need for information technology. Variables relating product variety to supply chain complexity can be obtained from studies by Shou et al. (2017), Bode and Wagner (2015), Gimenez et al. (2012) and Vaart \& Donk (2006). The effect of supply chain complexity on the need level of information technology can be investigated through information-sharing mechanism approach. This approach is based on the complexity of information exchanges, which have been addressed by Sivadasan et al. (2002), Sivadasan et al. (2006), Sivadasan et al. (2013), Welker et al. (2008) and Cheng et al. (2014).

\section{CONCLUSION}

The main objective of this paper is to review the literature on product variety, supply chain and information technology. Based on the literature review, a conceptual framework is developed. The conceptual framework highlights several propositions and areas for further study. First proposition is the potential relation between product variety and supply chain complexity. The increase of product variety leads to the complexity of material needed by companies to build a product. The growth of product and material variation lead to supply chain complexity i.e. complexity of business entities involved in the production of products or service exchanges, as well as material and information flow between each supply chain networks channels. Second proposition is the correlation between supply chain complexity and information technology. Supply chain complexity to some extent determine the information exchanges in the company's supply chain network. Thus, the information technology must allow the overall information to be exchanged effectively and efficiently among supply chain network channels. Thirdly, it is important for companies to align the implementation of information technology with the company's business condition. This way, the company can obtain more valuable benefit from implementation of information technology. Finally, the main propositions from this study is that there are potential connections among product variety, supply chain complexity, business condition and information technology.

\section{REFERENCES}

Aitken, J., Bozarth, C. and Garn, W. (2016) To eliminate or absorb supply chain complexity: a conceptual model and case study, Supply Chain Management: An International Journal, 21(6), pp. 759-774. doi: 10.1108/SCM-02-20160044.

Auramo, J., Kauremaa, J. and Tanskanen, K. (2005) Benefits of IT in supply chain management: an explorative study of progressive companies, International Journal of Physical Distribution \& Logistics Management, 35(2), pp. 82-100. doi: 10.1108/09600030510590282.

Bode, C. and Wagner, S. M. (2015) Structural drivers of upstream supply chain complexity and the frequency of supply chain disruptions, Journal of Operations Management. Elsevier B.V., 36, pp. 215-228. doi: 10.1016/j.jom.2014.12.004.

Cheng, C.-Y., Chen, T.-L. and Chen, Y.-Y. (2014) An analysis of the structural complexity of supply chain networks, Applied Mathematical Modelling. Elsevier Inc., 38(9-10), pp. 2328-2344. doi: 10.1016/j.apm.2013.10.016.

Choi, T. Y. and Hong, Y. (2002) Unveiling the structure of supply networks : case studies in Honda, Journal of Operations Management, 20, pp. 469-493. doi: 10.1016/S02726963(02)00025-6.

Cole, R. E. (2010) Toyota's Hyper Growth and Complexity Trap, Harvard Business Review. Available at: https://hbr.org/2010/02/toyota-the-downside-of-hyper-g.

Cooper, M. C. and Ellram, L. M. (1993) Characteristics of Supply Chain Management and the Implications for Purchasing and Logistics Strategy, International Journal of Logistics Management, 4(2), pp. 13-24. doi: $10.1108 / 09574099310804957$.

Cooper, M., Lambert, D. and JD (1997) Supply chain management: more than a new name for logistics, The International Journal of Logistics Management, 8(1), pp. 1-14. doi: 10.1108/09574099710805556.

ElMaraghy, H. et al. (2009) Managing variations in products, processes and manufacturing systems, CIRP Annals Manufacturing Technology, 58(1), pp. 441-446. doi: 10.1016/j.cirp.2009.04.001.

ElMaraghy, H. et al. (2013) Product variety management, CIRP Annals - Manufacturing Technology, 62(2), pp. 629-652. doi: 10.1016/j.cirp.2013.05.007.

Fuchs, C. and Otto, A. (2015) Value of IT in supply chain planning, Journal of Enterprise Information Management, 28(1), pp. 77-92. doi: 10.1108/JEIM-07-2013-0053.

Gimenez, C., Van Der Vaart, T. and Van Donk, D. P. (2012) Supply chain integration and performance: the moderating effect of supply complexity, International Journal of Operations \& Production Management, 32(5), pp. 583-610. doi: $10.1108 / 01443571211226506$.

Inman, R. R. and Blumenfeld, D. E. (2014) Product complexity and supply chain design, International Journal of Production Research, 52(7), pp. 1956-1969. doi: 10.1080/00207543.2013.787495.

Kaliani Sundram, V. P., Chandran, V. and Awais Bhatti, M. (2016) Supply chain practices and performance: the indirect effects of supply chain integration, Benchmarking: An International Journal, 23(6), pp. 1445-1471. doi: 10.1108/BIJ-03-2015-0023.

Khan, O. and Creazza, A. (2009) Managing the product designsupply chain interface: Towards a roadmap to the design centric business, International Journal of Physical Distribution \& Logistics Management, 39(4), pp. 301-319.

Kitchenham, B. et al. (2009) Systematic literature reviews in software engineering - A systematic literature review, 
Information and Software Technology. Elsevier B.V., 51(1), pp. 7-15. doi: 10.1016/j.infsof.2008.09.009.

Lambert, D. M., Cooper, M. C. and Pagh, J. D. (1998) Supply Chain Management: implementation issues and research opportunities, Inernational journal of logistics management, $9(2), \quad$ pp. $\quad 1-19 . \quad$ doi: $10.1108 / 09574099810805807$.

de Leeuw, S., Grotenhuis, R. and van Goor, A. R. (2013) Assessing complexity of supply chains: evidence from wholesalers, International Journal of Operations \& Production Management, 33(8), pp. 960-980. doi: 10.1108/IJOPM-072012-0258.

Mentzer, J. T. et al. (2001) Defining Supply Chain Management, Journal of Business Logistics, 22(2), pp. 1-25. doi: 10.1002/j.2158-1592.2001.tb00001.x.

Motiwalla, L. F. and Thompson, J. (2012) Enterprise Systems for Management. Internatio. New Jersey: Pearson Education, Inc.

Novak, S. and Eppinger, S. D. (2001) Sourcing By Design: Product Complexity and the Supply Chain, Management Science, 47, pp. 189-204.

Perona, M. and Miragliotta, G. (2004) Complexity management and supply chain performance assessment. A field study and a conceptual framework, International Journal of Production Economics, 90(1), pp. 103-115. doi: 10.1016/S09255273(02)00482-6.

Pujawan, N., Er, M. and Somboonwiwat, T. (2014) Uncertainty and schedule instability in supply chain: Insights from case studies Uncertainty and schedule instability in supply chain, International Journal of Services and Operations Management, 19(November), pp. 468-490. doi: 10.1504/IJSOM.2014.065670.

Qrunfleh, S. and Tarafdar, M. (2014) Supply chain information systems strategy: Impacts on supply chain performance and firm performance, International Journal of Production Economics. Elsevier, 147(PART B), pp. 340-350. doi: 10.1016/j.ijpe.2012.09.018.

Randall, W. S. et al. (2011) Retail supply chain management: key priorities and practices, International Journal of Logistics Management, 22(3), pp. 390-402. doi: 10.1108/09574091111181381.

Ross, J. W. and Mocker, M. (2017) The Problem with Product Proliferation, Harvard Business Review, pp. 104-110. Available at: https://hbr.org/2017/05/the-problem-withproduct-

proliferation?utm_campaign $=h b r \& u t m \_s o u r c e=t w i t t e r \& u t$ m_medium $=$ social.

Shou, Y., Li, Y., Park, Y.W., and Kang, M. (2017) The Impact of Product Complexity and Variety on Supply Chain Integration, International Journal of Physical Distribution \& Logistics Management, 47(4). doi: http://dx.doi.org/10.1108/IJPDLM-03-2016-0080.

Sivadasan, S., Efstathiou, J., Frizelle, G., Shirazi, R., and Calinescu, A. (2002) An information-theoretic methodology for measuring the operational complexity of supplier-customer systems, International Journal of Operations \& Production Management, 22(1), pp. 80-102. doi: 10.1108/01443570210412088.

Sivadasan, S., Efstathiou, J., Calinescu, A., and Huatuco, L. H
(2006) Advances on measuring the operational complexity of supplier-customer systems, European Journal of Operational Research, 171(1), pp. 208-226. doi: 10.1016/j.ejor.2004.08.032.

S Sivadasan, S., Smart, J., Huatuco, L. H. and Calinescu, A. (2010) Operational complexity and supplier-customer integration: case study insights and complexity rebound, Journal of the Operational Research Society. Palgrave Macmillan, 61(12), pp. 1709-1718. doi: 10.1057/jors.2009.138.

S Sivadasan, S., Smart, J., Huatuco, L. H. and Calinescu, A. (2013) Reducing schedule instability by identifying and omitting complexity-adding information flows at the suppliercustomer interface, International Journal of Production Economics. 145(1), pp. 253-262. doi: 10.1016/j.ijpe.2013.04.043.

Vaart, T. Van Der and Donk, D. P. Van (2006) Buyer-focused operations as a supply chain strategy: Identifying the influence of business characteristics, International Journal of Operations \& Production Management, 26(1), pp. 8-23. doi: $10.1108 / 01443570610636996$.

Vanpoucke, E., Vereecke, A. and Muylle, S. (2017) Leveraging the impact of supply chain integration through information technology, International Journal of Operations \& Production Management, 37(4), pp. 510-530. doi: 10.1108/IJOPM-07-2015-0441.

Wagner, B. and Weidner, S. (2016a) Module SAP: Materials Management ( $M M)$.

Wagner, B. and Weidner, S. (2016b) Module SAP: Sales and Distribution (SD).

Wagner, B., Weidner, S. and Boldau, M. (2016) Module SAP. Controlling ( $\mathrm{CO}$ ).

Wan, X., Evers, P. T. and Dresner, M. E. (2012) Too much of a good thing: The impact of product variety on operations and sales performance, Journal of Operations Management. 30(4), pp. 316-324. doi: 10.1016/j.jom.2011.12.002.

Welker, G. A., van der Vaart, T. and Pieter van Donk, D. (2008) The influence of business conditions on supply chain information-sharing mechanisms: A study among supply chain links of SMEs, International Journal of Production Economics, 113(2), pp. 706-720. doi: 10.1016/j.ijpe.2007.04.016.

Ye, F. and Wang, Z. (2013) Effects of information technology alignment and information sharing on supply chain operational performance, Computers \& Industrial Engineering. 65(3), pp. 370-377. doi: 10.1016/j.cie.2013.03.012.

Zhang, X., Pieter van Donk, D. and van der Vaart, T. (2011) Does ICT influence supply chain management and performance?, International Journal of Operations \& Production Management, 31(11), pp. 1215-1247. doi: $10.1108 / 01443571111178501$.

Zhou, H., Shou, Y., Zhai, X., Li, L. Wood, C. and Wu, X. (2014) Supply chain practice and information quality: A supply chain strategy study, International Journal of Production Economics. Elsevier, 147(PART C), pp. 624-633. doi: 10.1016/j.ijpe.2013.08.025.

Estu Rizky Huddiniah received her bachelor's degree in information systems from Institut Teknologi Sepuluh Nopember, Surabaya in September 2015. Shortly after, she was awarded a scholarship to pursue a master's degree in the same Department. Her research interest is in Supply Chain Management and Modelling. She joined in Enterprise Systems Laboratory where she completed her master thesis in 2017.

Mahendrawathi ER received her bachelor degree in Industrial Engineering from Institut Teknologi Sepuluh Nopember, Surabaya, Indonesia and a master degree in operations management and manufacturing systems and a doctoral degree in 
manufacturing engineering and operations management both from Nottingham University, Nottingham, United Kingdom. Since 2006, she became a lecturer in Information Systems Department, Institut Teknologi Sepuluh Nopember, Surabaya, Indonesia. She teaches among others Enterprise Resource Planning, Business Process Management, Supply Chain Management, and e-business. She is a member of Enterprise Systems Research Lab. Her research interests are supply chain management, business process management and enterprise systems. Dr. Mahendrawathi has published her work in international journals and conferences. 